\title{
Performance Evaluation of a Rice (Oryza sativa) Thresher
}

\author{
${ }^{* 1}$ Sarafadeen K. Shittu and ${ }^{2}$ Nnaemeka M. Ezeh \\ ${ }^{1}$ Department of Agricultural and Environmental Engineering, Bayero University, Kano, Nigeria \\ ${ }^{2}$ Federal Ministry of Agriculture and Rural Development, Abuja, Nigeria \\ skshittu.age@buk.edu.ng|nnamekeze@yahoo.com
}

Received: 27-JUL-2021; Reviewed: 12-SEP-2021; Accepted: 20-SEP-2021

http://dx.doi.org/10.46792/fuoyejet.v6i3.676

\begin{abstract}
A paddy thresher supplied to the Department of Agricultural and Environmental Engineering, Bayero University, Kano Nigeria as part of its takeoff equipment for teaching and learning was evaluated to determine its performance indices in terms of threshing efficiency, cleaning efficiency, output capacity, mechanical damage and scatter loss. The variables used were two levels of moisture content $(20 \%$ and $14 \%)$, two levels of speed (500 rpm and $700 \mathrm{rpm})$ and feed rate at two levels $(100 \mathrm{~kg} / \mathrm{hr}$ and $150 \mathrm{~kg} / \mathrm{hr})$. The factorial experiments were run in a complete randomized design in three replications. Two local Rice varieties Sipi (variety 1) and Jemila (variety 2) were used. Analysis of Variance (ANOVA) and LSD were used to assess the effects of the independent variables on the performance indices of the paddy thresher. The mean values for cleaning efficiency, mechanical damage, scatter loss and output capacity ranges from $59.28-87.82 \%, 0.02-0.23 \%$, $0.02-0.05 \%$ and $25.26-58.82 \mathrm{~kg} / \mathrm{h}$ respectively. ANOVA results showed that moisture content, feed rate and speed significantly affected cleaning efficiency, mechanical damage and the output capacity at $5 \%$ probability for the two paddy varieties.
\end{abstract}

Keywords- Efficiency, output capacity, performance, rice, threshing machine

\section{INTRODUCTION}

$\mathrm{R}$ ice is among the world's leading cereals that feeds a large population of the world (Zhout et al., 2002). Rice has become one of the most important foods in Nigeria, consumed by both the rich and the masses. It is cultivated in virtually all the agro-ecological zones in Nigeria (Akande, 2001). Figure 1 shows that paddy production in Nigeria has been on the increase in recent years. The official data of the Food and Agriculture Organization of the United Nations (FAO) for paddy production in Nigeria stands at 8.4 million tonnes in 2019. As shown in Fig. 1, the production is on the increase, but the demand for rice in Nigeria yet surpasses its production level. Hence, Nigeria spends a lot of money on rice importation annually and this can only be averted by further increasing the production and seriously improving the processing of Nigerian rice.

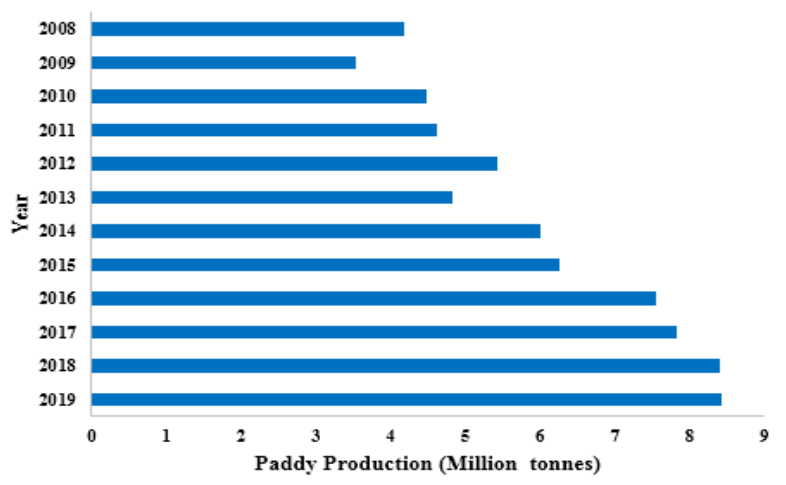

Fig. 1: Paddy production in Nigeria (FAOSTAT, 2021)

\footnotetext{
${ }^{*}$ Corresponding Author

Section A- AGRICULTURAL ENGINEERING \& BIOLOGICAL SCIENCES Can be cited as:

Shittu S.K. and Ezeh N.M. (2021): Performance Evaluation of a Rice (Oryza sativa) Thresher, FUOYE Journal of Engineering and Technology (FUOYEJET), 6(3), 5-9. http://dx.doi.org/10.46792/fuoyejet.v6i3.676
}

The poor acceptance of local rice in Nigeria has to do with its processing which is usually done manually. For instance, the threshing of rice is usually done by pounding the crop in a mortar using a pestle or by its flailing on the threshing drum or floor using sticks by farmers. These traditional methods of rice threshing are not only time-consuming but also laborious and of very low output (Joshi, 1981). The method introduces stone particles and pebbles and poses danger to the health of consumers.

Generally, the major steps involved in rice processing after harvesting include Threshing, pre-cleaning, destoning, parboiling, milling/ dehusking, huskseparation, whitening, polishing, grading, colour sorting and bagging. Rice threshing is the first and important unit operation carried out on the paddy straw to remove paddy from the straws after harvesting. According to Kepner et al., (1982), the performance of most threshers is dependent upon the moisture level of the crop, the peripheral speed of the cylinder, the clearance between concave and cylinder as well as the feed rate of the machine. Based on these factors, many previous works (Ramteke and Sirohi, 2003); Alizadeh and Khodabakhshipour, 2010; Fulani et al., 2013) have determined the ideal moisture content, the best peripheral speed of the cylinder, the ideal clearance of drum and cylinder and the most adequate feed rate of various machines and crops to achieve the best result of the threshing of the different crops.

Parts of the effort to solve the problem of paddy threshing in Nigeria has made the Department of Agricultural and Environmental Engineering, Bayero University, Kano, Nigeria to acquire a paddy thresher for teaching and research purposes. The acquired thresher is made in Pakistan and its performance with the local variety of paddy is yet to be established. Hence, the present study was carried out to satisfy the need to establish the performance indices of this machine using two varieties of our local rice to ascertain its threshing efficiency. 
The objective of the study is to evaluate the performance of the paddy thresher using two varieties of local paddy Sipi and Jemila based on output capacity, shelling and cleaning efficiencies, scatter loss and kernel damage. The study is carried to establish the performance with the local varieties of paddy for optimum utilization and possible modification of the thresher.

\section{Materials and Methods \\ 2.1 SAMPLE PREPARATION}

About $40 \mathrm{~kg}$ each of freshly harvested Sipi and Jamila varieties of paddy plants were procured from farmers in the Lenge area of Janguza Kano, Nigeria. The samples were soaked in clean water for $24 \mathrm{~h}$ and the plants were then spread out in thin layer under the shed to dry naturally with ambient Air conditions until desired moisture levels were achieved by measuring with a digital moisture meter. The paddy with the required moisture content levels was sealed in polythene bags to maintain stable and uniform moisture content before threshing. A similar procedure was reported by (Muhammad et al., 2021).

\subsection{Machine Description and Working Principle}

The acquired paddy thresher is presented in Plate 1 . The machine is composed of five basic units namely; feed unit, threshing unit, blower unit, separation unit and delivery unit. The thresher has a throw-in feeding system with an open axial-flow peg tooth threshing drum that aids in the movement of materials. The threshing compartment works on the principle of impacts from several metallic bars and pegs mounted on its periphery. The crop mass is brushed onto the screen to remove grains and the straws are discharged as well chopped material for animal feed. While being threshed, the material undergoes a spiral motion in a closed cylindrical casing; hammered with a series of pegs to remove the grains.

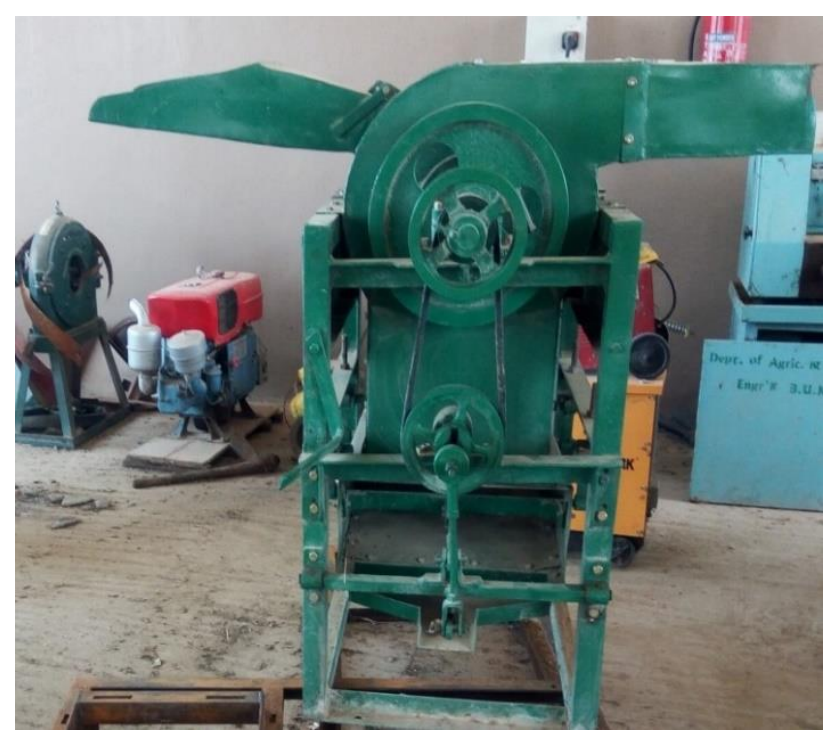

Plate 1: The Acquired Paddy Thresher

Finally, the grains and fine straw drops through the perforated concave and rolls over the inclined sheet metallic pan which leads the grain out while the straw is delivered to the straw outlet where it is discharged out. The thresher is powered by a 7-horsepower engine and the power from the engine to the threshing drum was transmitted through pulley and V- belts system. The harvested paddy is fed by throw-in method into the hopper of the machine. The majority of the grain is threshed during initial impact but further threshing takes place as the material moves axially in the thresher until the straw is discharged through delivery chute. The blower passes the airflow through the feed for the separation of chaff and other lighter material from the grain by passing air current. Threshed grain together with some impurities such as leaves and little pieces of straw, pass through the openings in the concave and are passed onto the screen where large impurities are screened out.

\subsection{Performance Evaluation Parameters}

The performance evaluation of the acquired paddy thresher was conducted in the Tractor Shed of the Department of Agriculture and Environmental Engineering, Bayero University, Kano, Nigeria. The speed of the thresher was adjusted by setting the throttle engine to the desired drum speed. About $5 \mathrm{~kg}$ of paddy was fed into the hopper and a feed rate control device was used to control the rate of feeding. The quantity of threshed paddy was collected from the delivery chute, and the time between the feeding and threshing was taken and recorded using a stopwatch. The un-threshed paddy and the straws were collected and weighed separately. The thresher performance was evaluated based on output capacity, threshing efficiency, cleaning efficiency, mechanical kernel damage and scatter losses.

Performance evaluation of the paddy thresher was determined using the following relation given by (Ndirika,1997).

Output Capacity, OC (kg/h): This can be defined as the capacity of the thresher to thresh a quantity of paddy per unit time.

$$
O C=\frac{Q s}{T}
$$

Where;

Qs = Quantity of threshed material that passed through the paddy collector $(\mathrm{kg})$

$T=$ Time taken to complete the threshing operation (h).

Threshing efficiency, $T e, \%$ : This is referred to as the ratio of the quantity of threshed grain (seeds) in the sample to the ratio of the total quantity of grains (seeds) in the sample.

$$
T e=100-\left(\frac{Q u}{Q t} \times 100\right)
$$

Where;

$Q u=$ Quantity of un-threshed paddy in the sample $(\mathrm{kg})$

$Q t=$ Total quantity of threshed paddy collected at the output $(\mathrm{kg})$.

Cleaning Efficiency, $\mathrm{Ce}(\%)$ : This is referred to as the ratio of the mass of clean paddy collected to that of the total mixture of paddy and chaff received at the outlet,

$$
C e=\frac{W c}{W t} \times 100
$$

Where;

$\mathrm{Wc}_{\mathrm{c}}=$ Weight of clean paddy collected at the main outlet of the thresher $(\mathrm{kg})$ 
$\mathrm{Wt}=$ Weight of total mixture of paddy and chaff collected at the main outlet $(\mathrm{kg})$

Mechanical Kernel Damage, Md (\%): It could be calculated by collecting the broken grains in the sample so that the grains damage would be determined in the threshed sample.

$$
M d=\frac{Q b}{Q t} \times 100
$$

Where;

$Q b=$ Quantity of broken paddy collected at the outlet per unit time $(\mathrm{kg})$

$Q t=$ Total quantity of paddy collected at the outlet per unit time $(\mathrm{kg})$

Scatter Losses, SL (\%): This is referred to as loss due to grain scattering around the thresher during operations.

$$
S L=\frac{Q e}{Q t} \times 100
$$

Where;

$Q e=$ Quantity of paddy scattered around the thresher $(\mathrm{kg})$ $Q t=$ Total quantity of paddy collected at the outlet per unit time $(\mathrm{kg})$

\subsection{EXPERIMENTAL DESIGN AND StATISTICAL ANALYSIS}

The performance tests of the paddy thresher were conducted for two local paddy varieties Sipi (variety 1) and Jemila (variety2). The experiments were done at two moisture content levels (14\% and 20\%), two levels of speeds (500 rpm and $700 \mathrm{rpm}$ ) and two levels of feed rates $(100 \mathrm{~kg} / \mathrm{h}$ and $150 \mathrm{~kg} / \mathrm{h})$. A completely randomized design in a $2 \times 2 \times 2 \times 2$ factorial experiment with three replications was used. The data obtained from the experiment were subjected to Statistical Analysis System (SAS) for analysis of variance in respect of the various performance indices. LSD was used to further analyse significant factors.

\section{RESULt AND Discussion}

In all the experimental runs, there was practically no unthreshed rice paddy observed. It therefore, shows that the threshing efficiency of the machine is $100 \%$ for the two varieties at two different moisture content levels. Even though there are scatter losses and mechanical damage but the quantity of un-threshed paddy in the samples after each threshing operation is zero. This performance is comparable to the work of Ndirika (1997). Table 1 presents the mean values for the cleaning efficiency, mechanical damage, scatter loss and output capacity for Sipi and Jemila variety. The results show that the mean values of the cleaning efficiency, mechanical damage, scatter loss and output capacity for Sipi ranges from 61.93 - $87.82 \%, 0.03-0.23 \%, 0.02-0.05 \%$ and $25.26-58.82 \mathrm{~kg} / \mathrm{h}$ respectively. The mean values of the cleaning efficiency, mechanical damage, scatter loss and output capacity for Jamila variety ranges from $59.28-84.85 \%, 0.02-0.18 \%$, $0.02-0.04 \%$ and $25.26-56.24 \mathrm{~kg} / \mathrm{h}$ respectively.

Table 2 presents the analysis of variance (ANOVA) results for the cleaning efficiency, mechanical damage, scatter loss and output capacity for Sipi and Jamila varieties of paddy. The table indicated that moisture content, feed rate and speed have a significant effect at $5 \%$ probability level on cleaning efficiency, mechanical damage and output capacity on both paddy varieties. The results show that speed has a significant effect on the scatter loss at $5 \%$ probability level but, moisture content and feed rate have no significant effect on the scatter loss for both varieties.

The results show that only the two-way interaction Mc $\mathrm{x}$ Fr has a significant effect on the cleaning efficiency at 5\% probability level for Sipi paddy variety, while the interactions Mc x Fr, Mc x S and Fr x S significantly affect cleaning efficiency, scatter loss and mechanical damage respectively, for Jamila paddy variety. Further analysis using LSD is presented in Table 3 for Sipi and Jamila varieties of paddy. The results show that, as the moisture contents increased from 14 to $20 \%$, the cleaning efficiencies of the thresher increased for the two paddy varieties with the cleaning efficiency of the Sipi variety higher than that of the Jamila variety. This is because at a lower moisture content there is more mixture of paddy and chaff collected at the main outlet probably as a result of the frail nature of the straw at the low moisture content.

\begin{tabular}{|c|c|c|c|c|c|c|c|c|c|c|}
\hline \multirow[b]{2}{*}{$\begin{array}{l}\text { Mc } \\
(\%)\end{array}$} & \multirow[b]{2}{*}{$\begin{array}{c}\text { Feed } \\
\text { rate } \\
(\mathrm{kg} / \mathrm{h})\end{array}$} & \multirow[b]{2}{*}{$\begin{array}{l}\text { Speed } \\
\text { (rpm) }\end{array}$} & \multicolumn{4}{|c|}{$\begin{array}{l}\text { Mean performance indices } \\
\text { for variety } 1 \text { (Sipi) }\end{array}$} & \multicolumn{4}{|c|}{$\begin{array}{l}\text { Mean performance indices } \\
\text { for variety } 2 \text { (Jemila) }\end{array}$} \\
\hline & & & $\begin{array}{l}\mathrm{Ce} \\
(\%)\end{array}$ & $\begin{array}{l}\mathrm{Md} \\
(\%)\end{array}$ & $\begin{array}{c}\mathrm{Sl} \\
(\%)\end{array}$ & $\begin{array}{c}\text { Oc } \\
(\mathrm{kg} / \mathrm{h})\end{array}$ & $\begin{array}{l}\mathrm{Ce} \\
(\%)\end{array}$ & $\begin{array}{l}\mathrm{Md} \\
(\%)\end{array}$ & $\begin{array}{l}\mathrm{Sl} \\
(\%)\end{array}$ & $\begin{array}{c}\text { Oc } \\
(\mathrm{kg} / \mathrm{h})\end{array}$ \\
\hline 14 & 100 & 500 & $79.32(6.01)$ & $0.03(0.00)$ & $0.05(0.00)$ & $26.72(1.75)$ & $67.03(9.92)$ & $0.02(0.01)$ & $0.02(0.01)$ & $25.26(5.39)$ \\
\hline 14 & 100 & 700 & $71.55(2.22)$ & $0.20(0.06)$ & $0.03(0.00)$ & $39.16(1.86)$ & $68.78(8.50)$ & $0.03(0.01)$ & $0.02(0.01)$ & $28.37(6.66)$ \\
\hline 14 & 150 & 500 & $62.80(5.81)$ & $0.03(0.01)$ & $0.03(0.00)$ & $25.26(5.39)$ & $59.28(14.65)$ & $0.03(0.01)$ & $0.02(0.01)$ & $29.42(7.20)$ \\
\hline 14 & 150 & 700 & $61.93(14.04)$ & $0.07(0.07)$ & $0.03(0.02)$ & $37.07(1.37)$ & 65.27 (12.03) & $0.03(0.01)$ & $0.02(0.01)$ & 30.48 (6.09) \\
\hline 20 & 100 & 500 & $83.70(9.16)$ & $0.03(0.01)$ & $0.02(0.01)$ & $58.82(0.00)$ & $82.20(6.74)$ & $0.14(0.08)$ & $0.04(0.01)$ & $\begin{array}{c}47.58 \\
(10.35)\end{array}$ \\
\hline 20 & 100 & 700 & $64.90(17.73)$ & $0.23(0.03)$ & $0.03(0.01)$ & 40.52 (18.05) & $84.85(8.96)$ & $0.15(0.08)$ & $0.04(0.01)$ & $48.09(9.69)$ \\
\hline 20 & 150 & 500 & $87.82(2.50)$ & $0.09(0.02)$ & $0.03(0.01)$ & 37.88 (13.12) & $79.20(6.11)$ & $0.16(0.08)$ & $0.04(0.01)$ & $\begin{array}{c}52.55 \\
(10.87) \\
\end{array}$ \\
\hline 20 & 150 & 700 & $75.55(0.09)$ & $0.07(0.06)$ & $0.03(0.02)$ & $52.56(20.74)$ & $80.96(7.28)$ & $0.18(0.07)$ & $0.04(0.01)$ & $\begin{array}{c}56.24 \\
(14.67) \\
\end{array}$ \\
\hline
\end{tabular}

Table 1. Mean performance indices for the two varieties of paddy 
Table 2. Analysis of variance for the varieties of paddy

\begin{tabular}{|c|c|c|c|c|c|c|c|c|c|c|c|c|}
\hline & \multicolumn{8}{|c|}{ ANOVA for variety 1 (Sipi) } & \multicolumn{4}{|c|}{ ANOVA for Variety 2 (Jamila) } \\
\hline & \multicolumn{2}{|c|}{$\begin{array}{l}\text { Cleaning } \\
\text { Efficiency }\end{array}$} & \multicolumn{2}{|c|}{$\begin{array}{c}\text { Mech. } \\
\text { Damage }\end{array}$} & \multicolumn{2}{|c|}{$\begin{array}{l}\text { Scatter } \\
\text { Loss }\end{array}$} & \multicolumn{2}{|c|}{$\begin{array}{l}\text { Output } \\
\text { Capacity }\end{array}$} & $\begin{array}{c}\text { Cleaning } \\
\text { Eff. }\end{array}$ & $\begin{array}{c}\text { Mech. } \\
\text { Damage }\end{array}$ & $\begin{array}{l}\text { Scatter } \\
\text { Loss }\end{array}$ & $\begin{array}{c}\text { Output } \\
\text { Cap. }\end{array}$ \\
\hline Source of variation & F Value & $\operatorname{Pr}>\mathrm{F}$ & F Value & $\operatorname{Pr}>\mathrm{F}$ & F Value & $\operatorname{Pr}>\mathrm{F}$ & F Value & $\operatorname{Pr}>\mathrm{F}$ & F Value & $\operatorname{Pr}>\mathrm{F}$ & F Value & $\begin{array}{l}\mathrm{Pr}>\mathrm{F} \\
\end{array}$ \\
\hline Rep. (R) & $0.76^{\mathrm{ns}}$ & 0.58 & $0.59^{\text {ns }}$ & 0.52 & $0.82^{\mathrm{ns}}$ & 0.49 & $0.58^{\mathrm{ns}}$ & 0.22 & $0.56^{\mathrm{ns}}$ & 0.50 & $3.29^{\mathrm{ns}}$ & 0.57 \\
\hline Moisture (Mc) & $4.05^{*}$ & 0.03 & $5.24^{*}$ & 0.03 & $2.49^{\mathrm{ns}}$ & 0.18 & $6.43^{*}$ & 0.02 & $5.55^{*}$ & 0.02 & $7.24^{*}$ & 0.04 \\
\hline Feed rate $(\mathrm{Fr})$ & $4.54^{*}$ & 0.04 & $6.09^{*}$ & 0.02 & $0.71^{\text {ns }}$ & 0.91 & $5.13^{*}$ & 0.03 & $0.54^{*}$ & 0.04 & $5.33^{*}$ & 0.04 \\
\hline Speed (S) & $4.67^{*}$ & 0.02 & $15.63^{*}$ & 0.02 & $0.82 *$ & 0.03 & $3.18^{*}$ & 0.05 & $6.61^{*}$ & 0.03 & $11.23^{*}$ & 0.03 \\
\hline $\mathrm{Mc} \times \mathrm{Fr}$ & $3.51^{*}$ & 0.02 & $0.31^{\mathrm{ns}}$ & 0.66 & $4.31^{\mathrm{ns}}$ & 0.12 & $0.28 \mathrm{~ns}$ & 0.28 & $2.11^{*}$ & 0.03 & $0.37^{\mathrm{ns}}$ & 0.59 \\
\hline Mc x S & $4.01^{\mathrm{ns}}$ & 0.17 & $0.03^{\text {ns }}$ & 0.91 & $3.58^{\mathrm{ns}}$ & 0.07 & $3.12^{\mathrm{ns}}$ & 0.18 & $2.1^{\text {ns }}$ & 0.16 & $0.05^{\mathrm{ns}}$ & 0.87 \\
\hline FrxS & $1.66^{\mathrm{ns}}$ & 0.40 & $18.70^{\mathrm{ns}}$ & 0.06 & $2.82^{\mathrm{ns}}$ & 0.37 & $4.88^{\mathrm{ns}}$ & 0.23 & $0.76^{\mathrm{ns}}$ & 0.32 & $12.30^{*}$ & 0.03 \\
\hline Mc $\times$ Fr $x S$ & $0.70^{\mathrm{ns}}$ & 0.98 & $2.04^{\mathrm{ns}}$ & 0.16 & 5.61 ns & 0.06 & $2.13^{\mathrm{ns}}$ & 0.10 & $0.00^{\mathrm{ns}}$ & 0.68 & $4.04^{\mathrm{ns}}$ & 0.18 \\
\hline
\end{tabular}

Table 3. Least Significant Difference for the performance indices using (Sipi) variety 1

\begin{tabular}{|c|c|c|c|c|c|c|c|c|c|}
\hline & & \multicolumn{4}{|c|}{ LSD for (Sipi) variety 1} & \multicolumn{4}{|c|}{ LSD for(Jamila) variety 2} \\
\hline & Treatment & $\begin{array}{l}\text { Cleaning } \\
\text { Efficiency }\end{array}$ & $\begin{array}{l}\text { Mechanical } \\
\text { Damage }\end{array}$ & $\begin{array}{c}\text { Scatter } \\
\text { Loss }\end{array}$ & $\begin{array}{l}\text { Output } \\
\text { Capacity }\end{array}$ & $\begin{array}{l}\text { Cleaning } \\
\text { Efficiency }\end{array}$ & $\begin{array}{c}\text { Mechanical } \\
\text { Damage }\end{array}$ & $\begin{array}{l}\text { Scatter } \\
\text { Loss }\end{array}$ & $\begin{array}{c}\text { Output } \\
\text { Capacity }\end{array}$ \\
\hline \multirow{3}{*}{$\begin{array}{l}\text { Moisture } \\
\text { Content (\%) }\end{array}$} & 14 & $68.90 \mathrm{~b}$ & $0.10 \mathrm{a}$ & - & $47.45 a$ & $58.74 \mathrm{~b}$ & $0.14 a$ & - & $40.45 a$ \\
\hline & 20 & $77.99 a$ & $0.08 \mathrm{~b}$ & - & $32.05 \mathrm{~b}$ & $67.59 \mathrm{a}$ & $0.09 \mathrm{~b}$ & - & $29.06 \mathrm{~b}$ \\
\hline & LSD & 11.49 & 0.05 & - & 14.19 & 12.39 & 0.05 & - & 13.18 \\
\hline \multirow{3}{*}{$\begin{array}{c}\text { Feed Rate } \\
(\mathrm{kg} / \mathrm{hr})\end{array}$} & 100 & $74.87 \mathrm{a}$ & $0.12 \mathrm{a}$ & - & $38.19 b$ & $76.67 \mathrm{a}$ & $0.14 \mathrm{a}$ & - & $38.36 \mathrm{~b}$ \\
\hline & 150 & $72.03 \mathrm{~b}$ & $0.06 \mathrm{~b}$ & - & $41.31 \mathrm{a}$ & $72.03 b$ & $0.05 \mathrm{~b}$ & - & $40.22 a$ \\
\hline & LSD & 11.49 & 0.05 & - & 14.19 & 12.50 & 0.05 & - & 14.19 \\
\hline \multirow{3}{*}{ Speed (rpm) } & 500 & $78.41 \mathrm{a}$ & $0.04 \mathrm{~b}$ & $0.04 \mathrm{a}$ & $37.17 \mathrm{~b}$ & $74.31 \mathrm{a}$ & $0.05 \mathrm{~b}$ & $0.03 \mathrm{~b}$ & $34.18 \mathrm{~b}$ \\
\hline & 700 & $68.48 \mathrm{~b}$ & $0.14 a$ & $0.05 b$ & $42.33 a$ & $58.48 \mathrm{~b}$ & $0.25 a$ & $0.04 a$ & $39.33 a$ \\
\hline & LSD & 11.49 & 0.05 & 0.012 & 14.19 & 10.41 & 0.06 & 0.013 & 14.21 \\
\hline
\end{tabular}

Note: Means with same letter are not significantly different

The trend of results agreed with Olayanju et al. (2019). It was observed that the cleaning efficiency of the thresher decreases as the feed rate of the thresher increases for both Sipi and Jamila varieties of paddy, similar results were obtained by Al-Shamiry and Yahya (2020). Cleaning efficiencies of the thresher were found to decrease with the increase in the speed of the threshing drum for both varieties of paddy, with Sipi variety having the higher cleaning efficiency. The relationship of speed with cleaning efficiency is corroborated with the findings of Olayanju et al. (2019) and Al-Shamiry and Yahya (2020).

The results of LSD show that, as the moisture contents of paddy increased, the mechanical damage decreased for the two varieties of paddy with the Jamila variety having the higher mechanical damage. This is maybe as a result of the brittle nature of the paddy grains at the low moisture content. It is evident that the mechanical damage of the paddy decreases as the feed rate increases for both Sipi and Jamila varieties of paddy, these results agreed with Al-Shamiry and Yahya (2020). The mechanical damages were found to increase with the increase in the speed of the threshing drum for both varieties of paddy, with Jamila variety having the higher mechanical damage. This is probably because a higher impact force is generated at a higher speed, hence more breakage is experienced under this condition. These results are in accord with the results of Dhananchezhiyan et al. (2013) and Al-Shamiry and Yahya (2020).

The LSD for scatter loss presented in Tables 3 for Sipi and Jamila varieties of paddy show that the scatter loss increased as the machine speed increase from 500 to 700 rpm for the paddy varieties. The result is in accord with the findings of Olayanju et al. (2019) and Al-Shamiry and Yahya (2020). It can be deduced that the Sipi variety has a higher scatter loss than the Jamila variety, this may be as a result of differences in the aerodynamic properties of the two varieties of paddy.

The results of LSD for the two varieties of paddy show that, as the moisture contents of paddy increased, the output capacity decreased for both Sipi and Jamila paddy varieties with the Sipi variety having the higher output capacity. A similar trend was observed by Dhananchezhiyan et al. (2013). The results show that the output capacity increase as the feed rate increases for both Sipi and Jamila varieties of paddy, these results agreed with Dhananchezhiyan et al. (2013) and Al-Shamiry and Yahya (2020). The output capacity of the thresher was found to increase with the increase in the speed of the threshing drum for both paddy varieties with the Sipi variety having the higher output capacity. At a higher speed, the machine tends to work faster and the quantity of threshed material that passed through the paddy collector is more at a higher speed. The results corroborated with the Dhananchezhiyan et al. (2013).

The results of LSD show that, as the moisture contents of paddy increased, the mechanical damage decreased for the two varieties of paddy with the Jamila variety having the higher mechanical damage. This is maybe as a result of the brittle nature of the paddy grains at the low moisture content. It is evident that the mechanical damage of the paddy decreases as the feed rate increases for both Sipi and Jamila varieties of paddy, these results 
agreed with Al-Shamiry and Yahya (2020). The mechanical damages were found to increase with the increase in the speed of the threshing drum for both varieties of paddy, with Jamila variety having the higher mechanical damage. This is probably because a higher impact force is generated at a higher speed, hence more breakage is experienced under this condition. These results are in accord with the results of Dhananchezhiyan et al. (2013) and Al-Shamiry and Yahya (2020).

The LSD for scatter loss presented in Tables 3 for Sipi and Jamila varieties of paddy show that the scatter loss increased as the machine speed increase from 500 to 700 rpm for the paddy varieties. The result is in accord with the findings of Olayanju et al. (2019) and Al-Shamiry and Yahya (2020). It can be deduced that the Sipi variety has a higher scatter loss than the Jamila variety, this may be as a result of differences in the aerodynamic properties of the two varieties of paddy.

The results of LSD for the two varieties of paddy show that, as the moisture contents of paddy increased, the output capacity decreased for both Sipi and Jamila paddy varieties with the Sipi variety having the higher output capacity. A similar trend was observed by Dhananchezhiyan et al. (2013). The results show that the output capacity increase as the feed rate increases for both Sipi and Jamila varieties of paddy, these results agreed with Dhananchezhiyan et al. (2013) and Al-Shamiry and Yahya (2020). The output capacity of the thresher was found to increase with the increase in the speed of the threshing drum for both paddy varieties with the Sipi variety having the higher output capacity. At a higher speed, the machine tends to work faster and the quantity of threshed material that passed through the paddy collector is more at a higher speed. The results corroborated with the Dhananchezhiyan et al. (2013).

\section{Conclusion AND ReCOMmENDATIONS 4.1 CONCLUSION}

The acquired paddy thresher was successfully evaluated using Sipi and Jemila rice varieties. In all the experimental runs, there was practically no un-threshed rice paddy observed. It therefore shows that the threshing efficiency of the machine is $100 \%$ for the two varieties at two different moisture content levels and speeds. Though there are scatter losses and mechanical damage but the quantity of un-threshed paddy in the samples after each threshing operation is zero. Moisture content, feed rate and speed significantly affected cleaning efficiency, mechanical damage and the output capacity for the two paddy varieties, but not these factors affected scatter loss of paddy.

\subsection{RECOMMENDATIONS}

From the analysis and discussion of the performance results of the paddy thresher and to improve on the performance, the following recommendation should be considered:

i. With the local varieties of paddy, the acquired paddy thresher performs satisfactorily in terms of threshing efficiency but will require improvement to reduce mechanical damage and scatter loss. ii. Using reverse engineering, an improved version of the machine should be developed at the Department of Agricultural and Environmental Engineering, Bayero University, Kano Nigeria.

iii. The fan on the blower should be improved to reduce clogging and thereby increasing the output capacity

iv. Wheels should be introduced to easy transportation of the threshing machine into the paddy farms.

\section{REFERENCES}

Akande, T. (2001). An Overview of the Nigerian Rice Economy, Research paper published by the Nigerian Institute of Social and Economic Research (NISER), Ibadan, 11

Al-Shamiry, F. M. S. and Yahya N. M. A. (2020). The Performance Evaluating of Thresher Machine Attached to the Tractor. IJRDO - Journal of Agriculture and Research. Volume-6 Issue-3. 7-16. ISSN: 2455-7668.

Alizadeh, M.R. and Khodabakhshipour, M. (2010). Effect of Threshing Drum Speed and Crop Moisture Content on The Paddy Grain Damage in Axial-Flow Thresher. Cercetări Agronomice în Moldova Vol. 43, No. 4, 144-155.

Dhananchezhiyan, P., Parveen, S. and Rangasamy, K. (2013). Development and Performance Evaluation of Low-Cost Portable Paddy Thresher for Small Farmers International Journal of Engineering Research \& Technology (IJERT). Vol. 2 Issue 7, 571585.

FAOSTAT (2019). http://www.fao.org/faostat/en/\#data/QC, retrieved 5th March, 2021.

Fulani, A.U., Kuje, J.Y. and Mohammed, B. I. (2013) Effect of Moisture Content on Performance of a Locally Fabricated Cowpea Thresher. Journal of Engineering and Applied Sciences Vol 5, No. 2. 1-13.

Joshi H C. (1981). Design and selection of thresher parameters and components. Agricultural Mechanization in Asia, Africa and Latin America (AMA); 21(3): 29-32.

Kepner, R. A., Roy, B., \& Barger E. L. (1982). Principles of farm machinery. (2nd ed.). The AvI Publishing Company Inc., Westport, U.S.A. 86-88.

Muhammad A. I., Isiaka M., Attanda M. L., Shittu S. K., Lawan I., Bomoi M. I. (2021). Acta Technologica Agriculturae Nitra, Slovaca Universitas Agriculturae Nitriae, Performance Optimization of Groundnut Shelling Using Response Surface Methodology. pp. 1-7

Ndirika VIO (1997) Modelling the performance of selected stationary Grain threshers Ph.D. Degree Thesis, Department of Agricultural Engineering, Ahmadu Bello University, Zaria, Nigeria.

Olayanju, A. T., Okonkwo C. E., Ojediran, J. O., Alake S. A., Alhassan, E. A. and Okunola, A. A. (2019). Design, Development and Evaluation of a Tangential-flow Paddy Thresher: A Response Surface Analysis. Asian J. Sci. Res., 12: 396-405.

Ramteke, A. S. and Sirohi, NPS. (2003). Studies on Design

Parameters for Linseed Crop Thresher. Journal of Agricultural Engineering, Vol. 40(2): 39 -45.

Zhout, Z., Robards, K., Heliwell, S., \& Blanchard, C. (2002). Ageing of stored rice; changes in chemical and physical attributes. Journal of Cereal Science, 35(1): 65-78. 